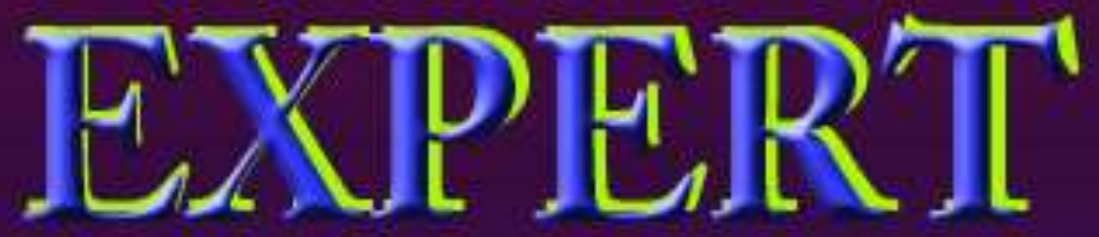

Jurnal Sistem Informasi

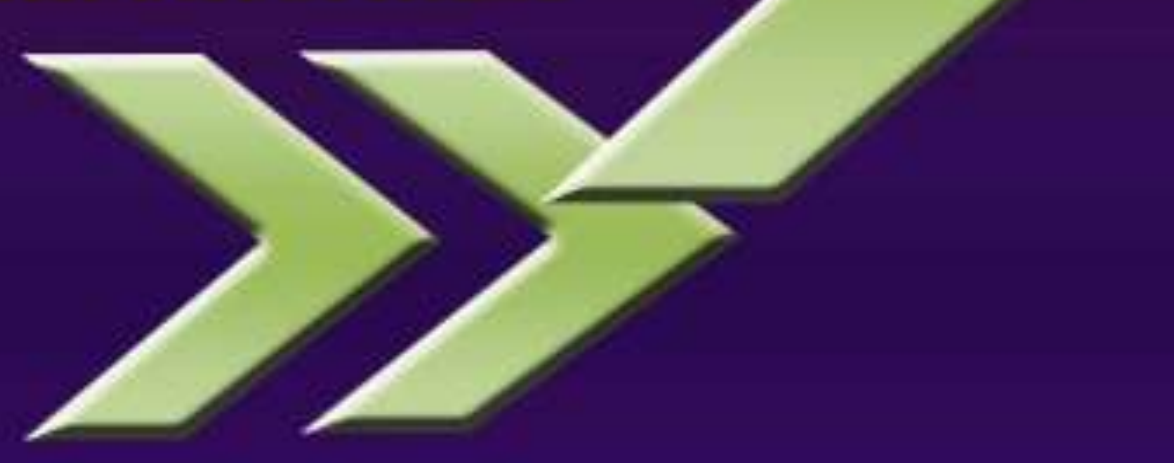

RANCANGAN SISTEM PENILAIAN OFFLINE BERBASIS KOMPUTER PADA SMP NEGERI 17 PESAWARAN

Nerry Wahyunt

PERANCANGAN SISTEM INFORMASI PADA BUTIK NENG ACHIE

Sri Ipuwati

PEMANFAATAN MEDIA INTERNET UNTUK MEMBANTU MENYUSUN DATA SISWA BERBASIS WEB PADA SMP PGRI 2 WAWAY KARYA LAMPUNG TIMUR

Reni Astika

MODEL KEBIJAKAN PDAM KAB.PRINGSEWU MENGGUNAKAN FUZZY ATRIBUT DECISSION MAKING (FMADM) DENGAN METODE SIMPLE ADDITIVE WEIGHTING (SAW)

Dewi Lidia Purwani, Riki Renaldo, Nungsiyati, Muhamad Muslihudin

E-QUESTIONER BERBASIS RANGKING METHOD UNTUK MEMPERMUDAH EVALUASI INDEKS KINERJA DOSEN

Fenty Ariasi, Yutbsi Aprilinda

SISTEM INFORMASI GEOGRAFIS PROFIL KOTA BANDAR LAMPUNG BERBASIS ANDROID (STUDI KASUS DINAS PARIWISATA PROVIL LAMPUNG)

Wiwis Susanty, Taqwan Thamrin, Yusinta Ria Disanda

ISSN : 2088-5555 


\section{Expert}

Jurnal Manajemen Sistem Informasi Dan Teknologi

Volume 06, Nomor 01, Juni 2016

\begin{tabular}{|c|c|}
\hline Judul & Hal \\
\hline $\begin{array}{l}\text { RANCANGAN SISTEM PENILAIAN OFFLINE BERBASIS } \\
\text { KOMPUTER PADA SMP NEGERI } 17 \text { PESAWARAN }\end{array}$ & $1-6$ \\
\hline $\begin{array}{l}\text { PERANCANGAN SISTEM INFORMASI PADA BUTIK } \\
\text { NENG ACHIE }\end{array}$ & $7-12$ \\
\hline $\begin{array}{l}\text { PEMANFAATAN MEDIA INTERNET } \\
\text { MEMBANTU MENYUSUN DATA SISWA } \\
\text { WEB PERBASIS } \\
\text { TIMUR }\end{array}$ & $13-16$ \\
\hline $\begin{array}{l}\text { MODEL KEBIJAKAN PRIORITAS DALAM UPAYA } \\
\text { MENINGKATKAN KINERJA PDAM KAB. PRINGSEWU } \\
\text { MENGGUNAKAN FUZZY ATRIBUT DECISSON MAKING } \\
\text { (FMADM) DENGAN METODE SIMPLE ADDITIVE } \\
\text { WEIGHTING (SAW) }\end{array}$ & $17-22$ \\
\hline $\begin{array}{llr}\text { E-QUESTIONER BERBASIS } & \text { RANGKING } & \text { METHOD } \\
\text { UNTUK MEMPERMUDAH } & \text { EVALUASI } & \text { INDEKS } \\
\text { KINERJA DOSEN } & & \end{array}$ & $23-31$ \\
\hline $\begin{array}{llll}\text { SISTEM INFORMASI GEOGRAFIS PROFIL } & \text { KOTA } \\
\text { BANDAR LAMPUNG BERBASIS ANDROID } & \end{array}$ & $32-41$ \\
\hline
\end{tabular}

Fakultas Ilmu Komputer

Universitas Bandar Lampung

\begin{tabular}{|c|c|c|c|c|}
\hline JMSIT & Volume 06 & Nomor 01 & $\begin{array}{c}\text { Lampung } \\
\text { Juni 2016 }\end{array}$ & $\begin{array}{c}\text { ISSN } \\
2088-5555\end{array}$ \\
\hline
\end{tabular}




\section{TIM PENYUNTING}

Ketua Tim Redaksi:

Taqwan Thamrin,ST,M.Sc

Penyunting Ahli

Mustofa Usman, Ph.D

Dr.Iing Lukman,M.Sc.

Usman Rizal, ST.,MMSI

Penyunting:

Fenty Ariani,S.Kom,M.Kom

Wiwin Susanty,S.Kom,M.Kom

Ayu Kartika Puspa,S.Kom,M.TI

Erlangga,S.Kom,M.Kom

Iwan Purwanto,S.Kom.,MTI

Pelaksana Teknis:

Zulkaisar, S.Kom

\section{Alamat Penerbit/Redaksi:}

Pusat Studi Teknologi Informasi

Fakultas Ilmu Komputer

Universitas Bandar Lampung

Gedung Business Center Lt. 2

J1,Zainal Abidin Pagar Alam No.26

Bandar Lampung

Telp.0721 - 774626

Email: Journal.expert@ubl.ac.id 


\title{
PEMANFAATAN MEDIA INTERNET UNTUK MEMBANTU MENYUSUN DATA SISWA BERBASIS WEB PADA SMP PGRI 2 WAWAY KARYA LAMPUNG TIMUR
}

\author{
Reni Astika, M.Kom \\ Dosen Program Studi Manajemen Informatika \\ Amik Dian Cipta Cendikia Bandar Lampung \\ astikarenieyahoo.com
}

\begin{abstract}
Abstrak
Sekolah Menengah Pertama (SMP) PGRI 2 Waway Karya Lampung Timur, bertujuan untuk ikut serta dalam kegiatan mencerdaskan kehidupan bangsa dengan berpartisipasi dalam dunia pendidikan. Siswa siswa yang di didik di sana merupakan siswa yang melanjutkan studi dari jenjang sebelumnya, mereka berdomisili dari daerah sekitarnya. Untuk mendapatkan informasi mengenai sekolah tersebut, masyarakat mendapatkannya langsung hanya dari siswa maupun guru yang belajar dan mengajar disana. Hal ini berkendala bagi calon siswa yang ada diluar daerah tersebut. Dalam penelitian untuk membuat Sistem Informasi Data Siswa Berbasis Web, peneliti menggunakan metodologi penelitian Extreme Programming dengan alat bantu pengembangan sistemnya yaitu UML (Unifeld Modelling Language) berupa Usecase, Diagram Aktifitas, dan Class Diagram, guna menggambarkan semua kegiatan dan aktifitas yang dilakukan ataupun yang akan dibuat dalam penelitian ini. Hasil langsung yang dapat dirasakan setelah Sistem Informasi Data Siswa SMP PGRI 2 Waway Karya Lampung Timur di upload di internet adalah kemudahan user dalam memperoleh informasi data mengenai sekolah ini, informasi data siswa, fasilitas yang ada dan juga bisa mempermudah calon siswa untuk dapat melakukan pendaftaran siswa baru disekolah ini dengan hanya mengakses diinternet. Sehingga lebih mudah, cepat dan bisa dilakukan kapan saja.
\end{abstract}

Kata Kunci $\quad$ : Web, Unifeld Modelling Language, Usecase.

\section{Pendahuluan}

Pada zaman sekarang ini, perkembangan dan pengaruh teknologi informasi di indonesia semakin canggih. Terutama dalam dunia internet yang terus berkembangan dengan pesat yang berpengaruh pada dunia perdagangan maupun dunia pendidikan. Internet berasal dari kata Interconnection networking yang mempunyai arti hubungan berbagai komputer dan berbagai tipe komputer yang membentuk sistem jaringan yang mencakup seluruh dunia (jaringan global) dengan melalui jaringan komunikasi seperti wireless dan lainnya. Dunia pendidikan sebenarnya merupakan kegiatan pembelajaran dan pengajaran untuk mengembangakan ilmu pengetahuan yang dilakukan oleh manusia di dunia ini. Sejalan perkembangan waktu, cara dan sarana yang digunakan untuk dunia pendidikan senan tiasa berubah. Bentuk pendidikan terbaru yang menginformasikan pengetahuan dan datanya sudah memanfaatkan sistem informasi berbasis web.

Penggunaan web dalam informasi dunia pendidikan misalnya informasi tentang data mahasiswa, perkembangan tempat pendidikan tersebut, pendaftaran siswa baru dan informasi nilai maupun perkembangan kegiatan sekolah menjadi lebih instan. Sehingga kita tidak perlu pergi ke sekolah tersebut untuk mengetahui informasi tersebut. Semua dapat dilakukan hanya dimana saja dan kapan saja dengan waktu dan tempat yang tidak terbatas.

Dari uraian diatas, peneliti berkeinginan untuk membuat suatu sistem informasi yang bisa meningkatkan nilai informasi tentang sebuah Sekolah Menengah Pertama dengan memanfaatkan jaringan internet. Atas dasar tersebut, penelitian ini mengangkat judul " Sistem Informasi Data Siswa berbasis Web pada SMP PGRI 2 Waway Karya Lampung Timur".

\section{Landasan Teori}

A. Sekolah menengah pertama (SMP)), Bahasa Inggris: junior high school) adalah jenjang pendidikan dasar pada pendidikan formal di Indonesia setelah lulus sekolah dasar (atau sederajat). Sekolah Menengah Pertama ditempuh dalam waktu 3 tahun, mulai dari kelas 7 sampai kelas 9. Pada tahun ajaran 1994/1995 hingga 2003/2004, sekolah ini pernah disebut sekolah lanjutan tingkat pertama (SLTP).

Murid kelas 9 diwajibkan mengikuti Ujian Nasional (dahulu Ebtanas) yang memengaruhi kelulusan siswa. Lulusan sekolah menengah pertama dapat melanjutkan pendidikan ke sekolah menengah atas atau sekolah menengah kejuruan atau sederajat.

Pelajar sekolah menengah pertama umumnya berusia 13-15 tahun. Di Indonesia, setiap warga 
negara berusia 7-15 tahun tahun wajib mengikuti pendidikan dasar, yakni sekolah dasar (atau sederajat) 6 tahun dan sekolah menengah pertama (atau sederajat) 3 tahun.Sekolah Menengah Pertama diselenggarakan oleh pemerintah maupun swasta.

Sejak diberlakukannya otonomi daerah pada tahun 2001, pengelolaan Sekolah Menengah Pertama Negeri di Indonesia yang sebelumnya berada di bawah Departemen Pendidikan Nasional, kini menjadi tanggung jawab pemerintah daerah kabupaten/kota. Sedangkan Departemen Pendidikan Nasional hanya berperan sebagai regulator dalam bidang standar nasional pendidikan. Secara struktural, sekolah menengah pertama negeri merupakan unit pelaksana teknis dinas pendidikan kabupaten/kota.

Di beberapa negara, SMP berlaku sebagai jembatan antara sekolah dasar dengan sekolah menengah atas. Namun istilah tersebut dapat dipergunakan secara berbeda di beberapa negara, kadang-kadang saling berbanding terbalik.

\section{B. Internet}

Internet adalah sebuah singkatan dari kata International Network, Internetworking dan Interceonnected Network, yang memiliki fungsi menghubungkan jaringan dari jaringan-jaringan computer yang ada didunia. Internet merupakan rangkaian penghubung jaringan computer yang dapat diakses secara umum diseluruh dunia, yang mengirimkan data dalam bentuk paket data berdasarkan standar InternetProtokol (IP) [Yuhefizar, 2008].

Layanan yang diberikan oleh internet antara lain adalah :

a. Penyebaran dan memperoleh informasi

b. Berkomunikasi

c. Mengirim surat elektronik (Elektronic Mail/email)

d. Pertukaran data / transfer data

e. Remot login (Telnet)

Sedangkan Internet menurut [Maryono \& Petmi, 2008] merupakan kumpulan jaringan-jaringan computer sedunia yang salaing berhubungan satu dengan yang lain.

\section{Website}

Website adalah keseluruhan halaman-halaman website yang terdapat dalam sebuah domain yang mengandung informasi [Anhar, 2010]. Sebuah website biasanya dibangun atas banyak halaman website yang saling berhubungan. Hubungan antara satu halaman web dengan halaman web yang lain disebut dengan hyperlink, sedangkan teks yang dijadikan penghubung disebut hypertext [Yuhefizar, 2009].

\section{E-commerce}

E-commerce digunakan untuk mendukung kebiatan pembelian dan penjualan, pemasaran produk, jasa, dan informasi melalui internet atau extranet [Jusuf, 2008]. E-commerce umumnya dikelompokkan menjadi tiga kategori yaitu :

\section{a. Business-to-Business (B2B)}

B2B menyatakan penjualan produk atau jasa yang melibatkan beberapa perusahaan dan dilakukan dengan sistem otomatis. Umumnya perusahaan-perusahaan yang terlibat adalah pemasok, distributor, pabrik, toko, dll. Keuntungan B2B jika dikerjakan dengan benar, dapat menghemat biaya, meningkatkan pendapatan, mempercepat pengiriman, mengurangi biaya administrasi, dan meningkatkan layanan kepada pelanggan.

\section{b. Business-to-Consumer (B2C)}

B2C melibatkan interaksi dan transaksi antara sebuah perusahaan penjual dan para konsumen. Perusahaan-perusahaan terkenal yang melayani B2C antara lain adalah Dell (www.dell.com), Cisco (www.cisco.com), dan Amazon (www.amazon.com). Dalam praktiknya, jarang perusahaan yang hanya bermain B2C secara murni karena biasanya juga menyelenggarakan B2B.

\section{c. Consumer-to-Consumer (C2C)}

Consumer-to-consumer (C2C) atau terkadang disebut person-to-person menyatakan model perdagangan yang terjadi antara konsumen dengan konsumen melalui internet. Situs seperti eBay (www.ebay.com) dan Tokobagus.com (www.tokobagus.com) adalah contoh situs yang menyediakan sarana yang memungkinkan orang-orang dapat menjual atau membeli barang diantara mereka sendiri.

\section{d. Consumer-to-Business (C2B)}

Beberapa situs sudah berinisiasi untuk mendukung bisnis yang berbasiskan konsumen ke pebisnis (Consumer-to-Business atau C2B). Secara prinsip, di C2B, individual menawarkan produk atau layanan ke perusahaan. Beberapa contoh situsnya yaitu www.surveyscout.com, www.fotolia.com dan www.jobster.com. 


\section{Metodologi Penelitian}

Tahap pengembangan sistem dalam penelitian ini menggunanakan metodologi extream programing. Aspek dasar XP terdiri dari berbagai teknik atau metode yang diterapkan.

\section{A. The Planning Game}

Pendekatan XP dalam perencanaan ini adalah merencanakan alat pengembangan apa yang akan digunakan, menentukan kebutuhan sistem, informasi apa yang diperlukan dan bagaimana bentuk proses yang akan dibuat.

\section{B. Small Releases}

Setiap release dilakukan dalam lingkup sekecil mungkin pada XP. Setiap bagian dari sistem dikerjakan sehingga pekerjaaan bisa berkesinambungan dan tidak saling tumpang tindih. Bagian atau unit dari perangkat lunak yang telah diselesaikan, maka hasil tersebut harus segera dipresentasikan dan didiskusikan dengan klien. Jika memungkinkan untuk menerapkan unit tersebut pada perusahaan, hal itu juga dapat dilakukan sekaligus sebagai tes awal dari penerapan keseluruhan sistem.

\section{Simple Design}

Simple Design sebagai salah satu unsur XP. Pembuatan use case, diagram aktifitas, class diadram dan lainnya dibuat dalam lingkup kecil dan sederhana. Tidak perlu melakukan antisipasi terhadap berbagai perubahan di kemudian hari. Dengan desain yang simpel apabila terjadi perubahan maka membuat desain baru untuk mengatasi perubahan tersebut dapat dengan mudah dilakukan dan resiko kegagalan desain dapat diperkecil.

\section{Refactoring}

Refactoring adalah Melakukan perubahan pada kode program dari perangkat lunak dengan tujuan meningkatkan kualitas dari struktur program tersebut tanpa mengubah cara program tersebut bekerja. Dengan Refactoring tim pengembang dapat melakukan berbagai usaha untuk meningkatkan kualitas program tanpa kembali mengulang-ulang proses desain.

\section{E. Testing}

Dalam XP tes dari program dilakukan setiap setelah selesai satu bagian selesai dilanjutkan kebagian yang lainnya, sehingga ketika program selesai sudah merupakan program yang sempurna tidak ada lagi kesalahan yang akan terjadi.

\section{Hasil Penelitian}

\section{A. Use Case}

Berikut adalah use case yang merupakan alur system informasi pengolahan data Siswa berbasis web.

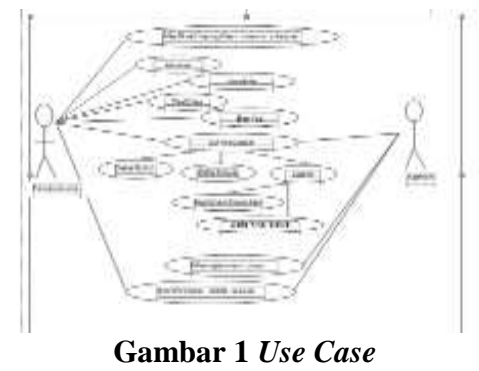

\section{B. Activity Diagram}

Berikut adalah activity diagram yang merupakan alur sistem pada Sistem Informasi data Siswa SMP PGRI 2 Waway Karya Lampung Timur:

\section{Diagram Login}

Activity dibawah ini menggambarkan alir aktivitas yang dilakukan dalam system website pada saat akan melakukan akses terhadap data penting.

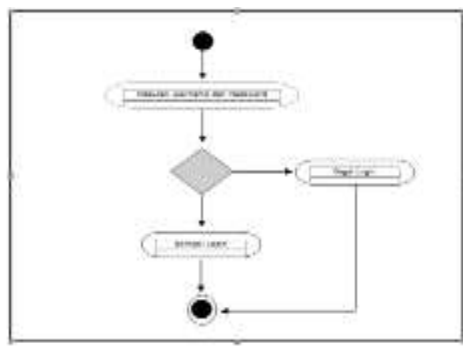

Gambar 2 Diagram Login

\section{Class Diagram}

Rancangan database yang digunakan pada pembangunan ecommerce ini adalah disajikan sebagai berikut:

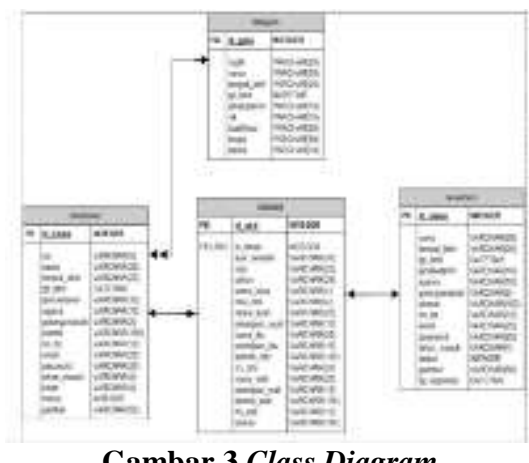

Gambar 3 Class Diagram 
Aplikasi yang dihasilkan, sebagai berikut :

\section{a. Tampilan Menu Utama}

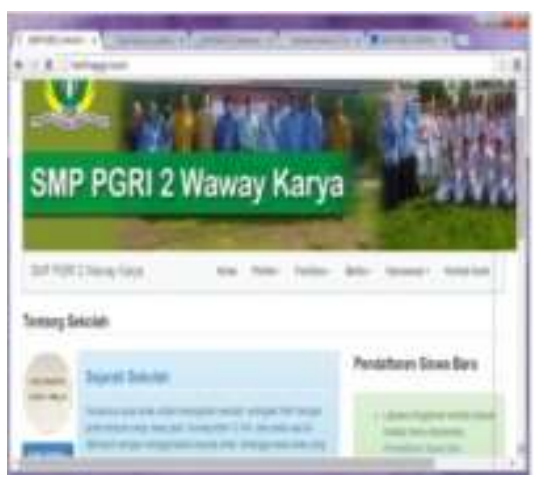

Gambar 4 Tampilan Menu Utama

\section{b. Tampilan Form Registrasi}

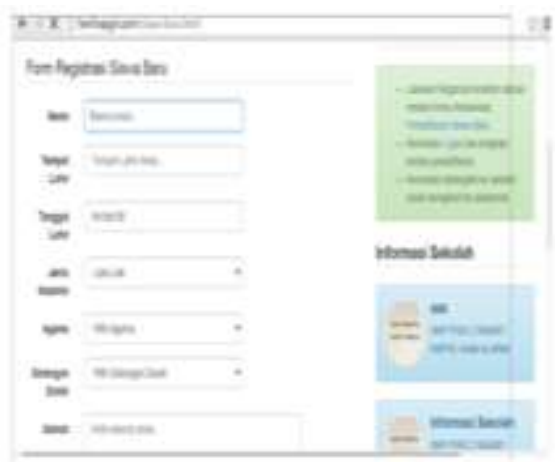

Gambar 5 Tamilan Form Registrasi

\section{c. Tampilan Menu Login}

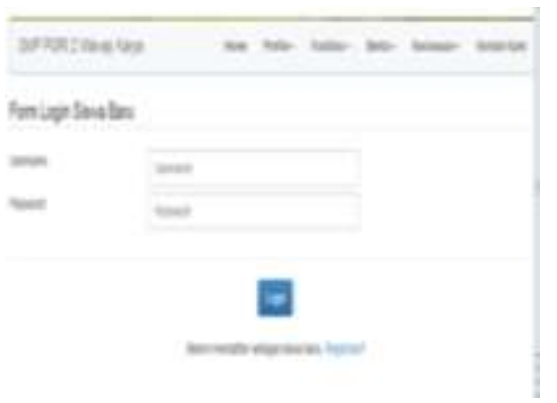

Gambar 6 Tampilan Menu Login

d. Tampilan Menu Form Kelengkapan Data Siswa

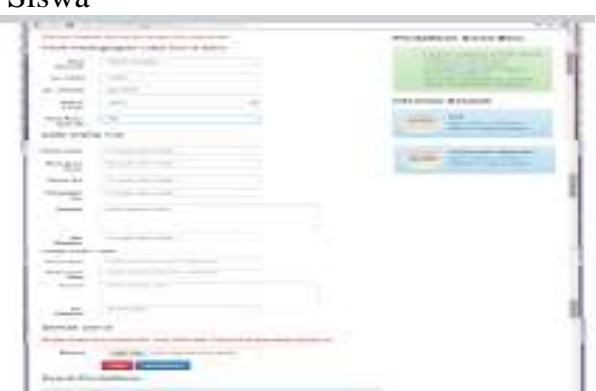

Gambar 7 Tampilan Menu Form Kelengkapan Data Siswa

\section{Kesimpulan}

Berdasarkan penelitian yang telah dilakukan, maka dapat diambil kesimpulan sebagai berikut :

1. Sistem informasi Siswa di SMP PGRI 2 Waway Karya Lampung Timur, selama ini masih dilakukan dengan cara mencari data langsung ke sekolahan tersebut, ataupun dengan menyebarkn informasi melaui siswa dan guru yang ada disana.

2. Bila dilihat dari segi tingkat promosi, Sistem Informasi Data Siswa yang dibuat secara online ini, diharapkan akan meningkatkan promosi dan nilai jual untuk SMP PGRI 2 Waway Karya. Yang nantinya diharapkan akan meningkatnya jumlah siswa yang masuk atau mendaftar disekolah tersebut.

\section{Daftar Pustaka}

[1] Abdul Kadir (2014 : 61) Pengenalan Sistem Informasi Edisi Revisi

[2] Anhar. 2010. Pandauan Menguasai PHP \& MySQL secara Otodidak. Mediakita. Jakarta.

[3] HM. Jogiyanto. 1999. Pengenalan Komputer dasar Ilmu Komputer, Pemrograman Sistem Informasi dan Inteligensi buatan. Penerbit Andi. Yogyakarta.

[4] Jusuf, Heni. 2008. Studi Tingkat Keamanan Kata Sandi pada Data, Email dan Aplikasi. Jurusan Sistem Informasi, Fakultas Teknologi Komunikasi dan Informatika, Universitas Nasional. Jurnal Basis Data, ICT Research Center UNAS. Vol. 3 No. 2 Nopember 2008. ISSN 1987-9483. Hlm 71-82.

[5] Maryono, T, \& Petmi Istana, B. 2008. Teknologi Informasi dan komunikasi 3. Quarda. Surabaya. 
Redaksi :

Pusat Studi Teknologi Informasi (PSTI). Gedung Business Center Lt 2 JI. Zainal Abidin No. 26 Bandar Lampung Telp. $0721-774626$ 